\title{
Capital Structure Management by Share Repurchase for Companies in Emerging Markets
}

\author{
Julia Kulik \\ Postgraduate student of the Department of Finance and Credit, Faculty of Economics, \\ Lomonosov Moscow State University: \\ 119234, Russia, Moscow, Leninskie Gory, number 1, building 46 \\ E-mail: iuliakulik@gmail.com

\section{Svetlana Makarova} \\ Candidate of Economic Sciences, Associate Professor of the Department of Finance and Credit, \\ Faculty of Economics, Lomonosov Moscow State University: \\ 119234, Russia, Moscow, Leninskie Gory, number 1, building 46 \\ E-mail: svtlmakarova@gmail.com
}

\begin{abstract}
According to foreign research into developed markets, share repurchasing influences the speed of adjustment of companies' capital structure to the target level. It is worth noting that the number of such research studies for emerging markets is rather small.

On the basis of an empirical study of a selection of 275 companies from BRICS countries involved in share repurchase for the period of 2005 to 2015 we prove here that share repurchase is an efficient method of correcting an existing capital structure, aligning it to approximate a target level in all BRICS countries. It should be noted that in accordance with our results, companies from Brazil and Russia show the highest speed of adjustment (within 63-80\%). This indicates that these companies are able to achieve the target structure within a very short period. Companies from the other countries (India, China, and South Africa) also show a rather high rate of the speed of adjustment (in the range of 44 to $49 \%$ ).

It is worth noting that apart from the share repurchase itself, characteristic features of the companies (as well as special characteristics of local economic factors where they are relevant) influence the speed of adjustment to the target capital structure. We also found out that the most significant factors which have positive effects on the speed of adjustment are the company size, its growth prospects, share of repurchased shares, economic growth rate, inflation rate in the country which adversely affect to a great extent the speed of adjustment to the target capital structure. For Russian companies the most significant determinants are the company size, share of repurchased shares and inflation rate.

An assessment of the speed of adjustment to the target capital structure of companies repurchasing shares showed that for Russian companies (for a balance sheet leverage) and for South African companies (for a market financial leverage) the speed of adjustment is not significant, however in general the countries selection and each sub-selection shows that BRICS countries' companies are prone to adjust to the target capital structure quicker when the financial leverage is lower than the target value, while companies with an excess debt load optimize much slower.

On the basis of the research results we offer an algorithm pertaining to capital structure management for the companies acting in emerging markets using share repurchase in an open market.
\end{abstract}

Keywords: capital structure; capital structure determinants; partial adjustment model; share repurchase; speed of adjustment; target capital structure.

JEL: G35, G32 


\section{Introduction}

The problem of management of the capital structure is studied extensively in literature commencing from publishing in 1958 the paper by Modigliani-Miller (MM). It is common knowledge that this theory is true for a perfect capital market, so over the past few decades scientists tried to introduce in the ideal MM world the "imperfections" inherent in the actual market, and this gave rise to dozens of theories on the structure of companies' capital. Notably, a compromise theory gained traction which is based upon the presumption that a company has a target capital structure. At the close of the twentieth century a great number of works (mainly in foreign literature) was dedicated to the study of the influence of the share repurchase procedure on the current companies' capital structure. Papers by [Bonaime et al., 2014; Wang et al., 2009; Koerniadi et al., 2007] revealed that in mature markets, companies shorten the distance to the target structure by share repurchase, and the difference between the target capital structure and the capital structure after repurchase in such companies is less than in similar companies which have not repurchased shares. Share repurchase is, therefore, an effective corporate management tool because it can influence significantly the company market value, its shares' price, ownership structure and its financial leverage. Advanced economies started to use the share repurchase procedure since the 1990s and each year the volume of transactions grows. According to Thomson Reuters, in 2016 S\&P 500 companies repurchased shares whose value amounted to 536 billion dollars. Along with this, the average annual rate of growth of the amount of repurchased shares in the period of 2000 to 2016 was approximately $9 \%{ }^{1}$.

In the meantime, in Russia, share repurchase by an issuer is a rather new and not entirely studied phenomenon. At the same time a lot of public companies in emerging markets (including Russia) repurchase shares and implement programs of share repurchase. Alongside this, there exists a rather small amount of research which reveals the influence of repurchase on companies' capital structure in emerging markets. Besides, little attention is devoted to revealing the influence of individual characteristic features of companies and macroeconomic performance of emerging markets on the speed of adjustment to the target capital structure as a result of share repurchase. Meanwhile, it behoves companies to fully understand the consequences of share repurchase (among other reasons for the sake of their shareholders' welfare), and take into consideration the economic status of the company itself and the features of the prevailing macroeconomic environment (for example, economic growth dynamics, inflation etc.). All the above reasons are motivating factors for the authors' interest to research in this sphere.

The first part of this publication analyses the mechanism of influence of the share repurchase procedure on the capital structure of companies and on the speed of adjustment to the target capital structure and substantiates the hypotheses of the study. The second part gives grounds for development of the model necessary for the research of influence of the share repurchase on attainment by the companies of the target capital structure. The third part states the justification for generating a specific selection of companies in BRICS countries and descriptive statistics of the selection. The fourth part is devoted to an analysis of the results of an empirical study aimed at revealing the nature of influence of the share repurchase procedure on the speed of adjustment of companies from developing economies to the target capital structure, as well as to identifying the most significant factors at play for various types of companies engaged in this activity. In this part, we also draw forth the differences in the speed of adjustment to the target capital structure of the companies in BRICS countries. Finally, in the fifth part of this paper, on the basis of study results, the authors describe the algorithm of management of the target capital structure using share repurchase for various types of companies taking into consideration the macroeconomic environment, which has been developed by them.

\section{Analysis of Literature and Substantiation of the Re- search Hypotheses}

In modern economic theory, the capital structure is understood as the ratio of debt capital to proprietary capital chosen by a company in accordance with its development strategy aimed at the solution of long-term tasks. As a rule, among the proprietary funds of a company are included its shares (ordinary and preferred ones), and many researchers include with borrowed funds mainly the company long-term debt. When studying the capital structure it is necessary to make explicit the difference between the notions of the target and optimal structure. The optimal capital structure is understood as a correlation of the debt and the company owned capital which maximizes the company value. However, as a matter of practice it is extremely difficult to evaluate such correlation as long as it is more frequent in the theories of the capital structure which reveal the optimal value on the basis of including a limited number of factors. For this reason, in the management of a company the capital structure target value is used, which is formed under the influence of internal and external factors, life cycle stages and which gives the company an opportunity to increase its value and to be in good progress.

Division into static and dynamic theories occurs in the literature dedicated to analysis of the capital structure most often. At the same time dynamic compromise models of the capital structure which give an opportunity not merely to study methods of attaining the target capital structure, but also to assess the speed of adjustment to it are developed rather rapidly. The compromise theory is based

${ }^{1}$ Stock Market Indicators: S\&P 500 Buybacks \& Dividends // Yardeni Research. - 2017. 
on the presumption that the company has a target capital structure which is chosen having regard to the balance between the marginal benefit of attracting debt financing and the possible marginal costs incurred by failure to fulfill obligations of debt servicing. Since the period of development of the compromise theory, a growing number of research papers has been dedicated to research into the costs of adjustment and the speed of adjustment of firms to the target capital structure.

The most commonly used model for evaluation of the speed of adjustment of the company capital structure to the target value is the partial adjustment model. The standard (single-stage) partial adjustment model is governed by the following equation:

$$
L E V_{j, t}-L E V_{j, t-1}=\lambda_{j}\left(L E V_{j, t}^{*}-L E V_{j, t-1}\right)+\varepsilon_{j, t} \text {, }
$$

where $L E V_{j, t}$ is the indicator of the capital structure of the $\mathrm{j}$-th company in the point of time $\mathrm{t}, L E V_{j, t}^{*}$ - indicator of the target capital structure of the $\mathrm{j}$-th company in the point of time $t, \lambda_{j}$ - speed of adjustment of the $j$-th company.

Speed of adjustment indicates how much the distance between the current capital structure of the company and its target value is reduced: the larger the indicator $\lambda$ value, the quicker the company acquires the target capital structure. If $\lambda<0$ the actual capital structure deviates even more from the target value within a given period. If $\lambda=0$ then within a given period the company capital structure has not approximated the target value. If $0<\lambda<1$ then the company capital structure gradually shortens the distance between the actual and target value.

This formula describes the process of change of the financial leverage where in each period the company financial leverage $L E V_{j, t}$ adjusts to the target value $L E V_{j, t}^{*}$ at the speed of $\lambda$. At the same time the leverage target value is an unobservable variable, however this target value is defined by a set of determinants $X$.

$$
L E V_{j t}^{*}=\alpha_{i}+\sum \beta_{i} X_{j, t}+\varepsilon_{j t},
$$

where $X_{j, t}$ is the vector of determinants of the target capital structure.

Thus, the unobservable target value of the leverage in equation (1) may be defined using the determinants of the target capital structure by substituting for equation (2) in equation (1), in this case rearrangement of summands results in distinguishing the speed of adjustment to the target capital structure $\lambda$ :

$$
L E V_{j, t}=\left(1-\lambda_{j}\right) L E V_{j, t-1}+\lambda_{j} \alpha_{i}+\lambda_{j} \sum \beta_{i} X_{j, t}+\varepsilon_{j t},
$$

where $L E V_{j, t}$ is the indicator of the capital structure of the $\mathrm{j}$-th company in the point of time $\mathrm{t} ; X_{j, t}$ is the vector of determinants of the target capital structure; $\lambda$ is the speed of adjustment.

The main drawback of the single-stage partial adjustment model is that the model assumes that the speed of adjustment to the target capital structure is homogeneous, i.e. it is identical for all considered companies. This fact prevents us from evaluating the influence of certain determinants, in particular share repurchase and its characteristics, on the speed of adjustment to the target capital structure. In this regard a necessity for using a two-stage evaluation method arises.

In accordance with the two-stage partial adjustment model at the first stage the target value of the financial leverage $\widehat{L E V_{j, t}^{*}}$ for each company is calculated using the values of coefficients and values of determinants of the target capital structure in consequence of evaluating equation (2). On the basis of the calculated values the value of deviation of the financial leverage from the target value is calculated:

$$
\widehat{D e v_{j, t}}=\widehat{L E V_{j, t}^{*}}-L E V_{j, t-1}
$$

where $\widehat{L E V_{j, t}^{*}}$ is the indicator of the target capital structure of the $\mathrm{j}$-th company in the point of time $\mathrm{t}, L E V_{j, t-1}$ is the indicator of the capital structure of the $j$-th company in the point of time $\mathrm{t}-1$.

When substituting the value of deviation from the target leverage (4) into equation (1) we get the final model specification:

$$
L E V_{j, t}-L E V_{j, t-1}=\lambda_{j} \widehat{D e v_{j, t}}+\varepsilon_{j, t}
$$

Evaluation of the model specification represented by equation (5) gives an opportunity to assess the influence of various determinants on the speed of adjustment of the company to the target capital structure and, among other things, to take into consideration the influence of share repurchase.

In order to evaluate the speed of adjustment of companies to the target value of debt taking into consideration their original position relative to the target value the paper by [Dang et al. , 2012] offered a mode switching partial adjustment model. This model gives the authors the opportunity to find out what the difference is between the speed of adjustment in the companies with the capital structure above and below the target value:

$$
\begin{aligned}
& L E V_{j, t}-L E V_{j, t-1}=\lambda_{1}\left(L E V_{j, t}^{*}-L E V_{j, t-1}\right) 1_{\left(q_{i \leq c}\right)}+ \\
& +\lambda_{2}\left(L E V_{j, t}^{*}-L E V_{j, t-1}\right) 1_{\left(q_{i>c}\right)}+\varepsilon_{j, t}
\end{aligned}
$$

where $1_{\left(q_{i t s c}\right)}$ is the indicator of the capital structure below the target value; $\lambda_{1}$ is the speed of adjustment for the companies with the capital structure below the target value; $1_{\left(q_{i t>c}\right)}$ is the indicator of the capital structure above the target value; $\lambda_{2}$. is the speed of adjustment for the companies with an excessive debt load ${ }^{2}$.

Another method of evaluation of the speed of adjustment to the target capital structure was proposed in the paper

${ }^{2}$ For the companies which capital structure is above the target value. 
by [Komera, Lukose, 2016]. The specific characteristic of this method consists in its taking into account the fact that the model dependent variable, that is the capital structure is a fractional value (share of borrowed funds in the company assets), therefore this method is called DPF (dynamic panel fractional estimator). Besides, this method is intended for evaluation of unbalanced dynamic panel data, and this is its compelling advantage. The DPF method is based on the partial adjustment model similar to equation (3) above. The main difference from model (3) lies in defining the values of the financial leverage variable: in order to take into account the fractional nature of the capital structure value an unobservable (latent) variable which is time-invariant, defined on the basis of evaluating equation (7) is used as a dependent variable.

$$
L E V_{j t}^{+}=\lambda_{j} L E V_{j, t-1}+\alpha_{i} \sum \beta_{i} X_{j, t}+\varepsilon_{j t} \cdot(7)
$$

Variable $L E V_{j t}^{+}$. is some kind of theoretical estimate and may be beyond the interval of zero to one. At the same time, in effect, the value of the financial leverage is usually limited to the assigned limits and may fail to comply with this restriction only in extreme cases. In view of this the values of the observed value of the leverage are subject to the following limitation:

$$
L E V_{j, t}=\left\{\begin{array}{c}
0, L E V_{j t}^{+} \leq 0, \\
L E V_{j t}^{+}, 0<L E V_{j, t}<1, \\
1, L E V_{j, t}^{+} \geq 1 .
\end{array}\right.
$$

The obtained observable dependent variable is doubly censored (limited) within the interval from zero to one. However, the evaluations obtained by this method are not always well-balanced. For example the paper by [Komera, Lukose, 2016] tested this method in emerging markets for the companies listed at Johannesburg Stock Exchange in the period of 2000 to 2010 . The obtained evaluation of the speed of adjustment for the financial leverage using the generalized method of moments (GMM) by Blundell-Bond amounted to 54\%, however the speed of adjustment using the DPF method amounted to $80 \%$. Consequently, the evaluations of the speed of adjustment of the capital sucture in an emerging market using this method may be overestimated significantly.

Thus, from now forth we will use the two-stage partial adjustment model and the mode switching partial adjustment model to evaluate the influence of the direction of deviation from the target capal structure on the speed of adjustment to it when repurchasing shares.

At this point, we shall seek to substantiate the hypotheses of the research concerning influence of share repurchase on the companies' speed of adjustment to the target capital structure.

Capital sucture theories forecast how and why a firm may make profit on share repurchase. In accordance with the signal model, the company management by share repur- chase gives to the market a positive signal (the repurchase signals of the company's large cash flows, of expected rise in incomes) which attracts investors and initiates growth of shares. It should be noted that many companies use this advantage and declare share repurchase in an open market (in order to initiate growth of the company shares) but never actually implement such repurchases. Nevertheless, declared and uncompleted repurchases may adversely affect the price of the company shares as well as its goodwill. In accordance with the compromise theory, companies with a capital structure below the target value may attain such value by share repurchase: share repurchase reduces the owned capital increasing the leverage ratio; if repurchase was implemented by attracting debt capital, the leverage grows still more.

[Dittmar, 2000] was among the first to use a selection of nonfinancial companies in the period of 1977 to 1996 from $\mathrm{CRSP}^{3}$ database to show that companies which have repurchased shares shorten the distance to the target structure (defined as median ratio of debt to assets in the industry) and such companies have a smaller difference between the target capital structure and the capital structure after repurchase than the companies which have not implemented repurchase. The research by [Bonaime et al., 2014] which involved 7,880 repurchases in an open market in the United States between 1990-2010 also proved the significance of the inducement for correcting the capital structure: the market response to share repurchase is stronger in correlation with how much more the company capital structure deviates from the target value before the repurchase.

However, the amount of research into the issue concerning the influence of share repurchase on attainment of the target capital structure in emerging markets (and specifically in the Russian market) is significantly smaller. Mainly, analysis of the influence of industry affiliation, macroeconomic and institutional factors on the speed of adjustment to the target capital structure of companies in emerging markets, in particular in BRICS countries, is made in the researches. At present the Russian literature offers virtually no researches dedicated to the influence of share repurchase on the speed of adjustment to the target value of debt load, provides no recommendations on management decisions as regards correcting the capital structure using share repurchase, thus bringing about the present research. Alongside this (taking into consideration the proven influence of share repurchases on the attainment by companies of the target value of debt load in mature markets) we will verify this dependency for emerging economies of BRICS countries. In this regard the first hypothesis of our research is enunciated as follows: Hypothesis 1: as a result of share repurchase the capital structure adjusts approximating the target value.

The amount and proportion of repurchased shares also influence significantly the capital structure of companies. 
According to research into mature markets made by [Bargeron et al., 2011], [Bonaime, 2012] small repurchases are considered by investors as means of attaining a more efficient capital allocation, as in those cases the market response is minimal and fluctuations in prices for shares are of small account. However the higher the amount of repurchased shares, the stronger the market's positive response, and accordingly the more significant correction of company capital structure results (as long as a greater reduction in company-owned capital takes place) [Bargeron et al., 2011]. [Chun, 2010] studied share repurchase programs in Germany, Italy, Great Britain and France in the period of 1990 to 2005 and reached the conclusion that the bigger the amount of repurchased shares is, the more the distance to the target capital structure shortens: a big amount of shares repurchased at any one time results in significant reduction of company-owned capital, thus increasing the financial leverage and the company will correct the capital structure quicker thus approximating it to the target value. As long as share repurchases in the Russian market differ in amount it is important for us to study the dependence of the speed of adjustment on the amount of repurchased shares. This conformity to principle has not been studied in the Russian market but we can assume existence of a similar dependence revealed in mature markets and test it. Hypothesis 2: the more the amount of repurchased shares is, the higher the speed of adjustment to the target capital structure achieved as a result of share repurchase.

A significant influence on the speed of adjustment is correlated with the distance and direction of deviation from the target capital structure. On the one hand, in accordance with the compromise theory the farther the company position is from the target capital structure, the bigger the alternative costs of deviation from it, and consequently, the speed of adjustment should be higher [Aybar-Arias et al., 2012]. On the other hand, if deviation from the target value of the financial leverage is significant and costs of adjustment are too high the company may elect not to correct the capital structure [Lemma, Negash, 2014]. The results of the majority of empirical papers [Bonaime, 2012; Andriosopoulos, Hoque, 2013] found out that in case of correcting the capital structure by means of share repurchase, the companies with the capital structure below the target value (the debt load is below the target value) have the highest speed of adjustment to the target capital structure. On the contrary, the companies with the debt load above the target value are greatly limited in the opportunity to attract joint-stock capital, and high cost of the capital and significant interest payments may lessen the company opportunities for debt repayment, this, in its turn, results in reduction of the speed of adjustment. As long as this hypothesis has not been tested for emerging markets we will verify it in the course of our research. $H y$ pothesis 3: the companies with an excessive debt load adjust to the target capital structure more slowly than the companies with the debt value below the target value resulting from share repurchase.
The company cash flows also influence significantly the costs of the capital structure optimization: if the company possesses large positive cash flows they may serve as a moderately priced source of share repurchase, thus reducing significantly the costs of financial leverage optimization. In case of negative cash flows the company faces the necessity to finance the repurchase procedure using borrowed funds. The paper by [Faulkender et al., 2012] revealed that companies with big absolute values of free cash flows have the highest speed of adjustment, while companies with big negative cash flows are forced to use outside financing in the form of a debt or joint-stock capital, depending on whether the leverage is above or below the optimum value. Hypothesis 4: companies with significant free cash flows as a result of share repurchase have higher values of the speed of adjustment.

Intra-corporate determinants of a company and macroeconomic factors also significantly influence the degree of success of share repurchases in correcting the capital structure. Consequently, we will phrase and substantiate below hypotheses on the nature of influence of such intra-corporate and external factors.

The company size is one of the main determinants of the speed of adjustment. First, major companies are characterized by an easier ability to access capital markets. Due to a high negotiating power when dealing with creditors, such companies have a smaller cost of debt [Mukherjee, Mahakud, 2010]. Second, due to widespread occurrence of analytical recommendations about major companies, a lower information asymmetry with creditors or investors is typical of them [Aybar-Arias et al., 2012]. Apart from that, major companies have significantly lower fixed costs pertaining to share repurchases than small companies [Chipeta, Mbululu, 2013]. Therefore, major companies have a higher speed of adjustment to the target capital structure. It should be noted that the influence of company size on the speed of adjustment to the target capital structure has been tested in the Russian market on numerous occasions [Kokoreva, 2013], but no empirical conclusions have been made with reference to share repurchase for Russia as well as for all BRICS countries. Hypothesis 5: company size exerts a significant positive influence on the speed of adjustment to the target capital structure as a result of share repurchase.

The next factor which influences significantly the capital structure as a result of share repurchase is the company opportunities for growth. Along with the possibility to attract debt financing, companies with great opportunities for growth are more attractive for external investors and this facilitates access to joint-stock capital. Access to debt capital as well as to joint-stock capital gives such companies the opportunity to be more flexible in their policy of fund raising and to adjust the capital structure to the target value quicker. In papers by [Drobetz, Wanzenried, 2006; Aybar-Arias et al., 2012; Chipeta, Mbululu, 2013; Komera, Lukose, 2016], the authors perceived a significant positive dependence between the speed of adjustment and opportunities for growth of the company. 
In consequence of the absence of empirical conclusions as regards influence of the companies' opportunities for growth on the speed of attainment of the target capital structure in emerging markets as a result of share repurchase we will test the hypothesis which was validated in mature markets, the more so, because we consider its logic to be correct. Hypothesis 6: the higher is the company opportunity for growth the higher is the speed of adjustment of the capital structure to the target value as a result of share repurchase.

The company's profitability also exerts a significant influence on the speed of adjustment to the target capital structure: more profitable companies may use internal sources to finance share repurchase as well as may raise borrowed funds on more favourable terms due to their financial stability. Consequently, lower costs of adjustment to the target capital structure are typical of such companies and the companies may raise funds quicker. Thus, a positive dependence between the company profitability and its speed of adjustment to the target capital structure was revealed in papers by [Cook, Tang, 2010; Haron et al., 2013]. We also may presume that for the companies in emerging markets profitability gives an opportunity to raise internal financing quickly and without additional costs and in view of this - to approximate quicker the target value by share repurchase. Hypothesis 7: the company profitability exerts a significant positive influence on the speed of adjustment to the optimum capital structure as a result of share repurchase.

It is also necessary to take into consideration the influence of macroeconomic factors on the speed of adjustment within the share repurchase procedure which influence the company shares quotation. Usually among macroeconomic determinants which influence the speed of adjustment, the GDP growth rate in the country and inflation rate are distinguished. High GDP growth rates have a favorable impact on the company's opportunity to raise funds in the capital markets, they get more possibilities to shorten the deviation from the target capital structure, and this results in increase of the speed of adjustment [Haas, Peeters, 2006]. A positive influence of GDP growth rate was also received in the paper by [McMillan, Camara, 2012] who studied the speed of adjustment for US companies in the period between 1991 to 2009. Hypothesis 8: the higher the economic growth of a country, the higher the speed of adjustment of the capital structure to the target value as a result of share repurchase.

A high inflation rate exerts a significant influence on the balance sheet values of the debt and joint-stock capital giving the companies the opportunity to influence more the balance sheet values of the leverage, increasing the speed of adjustment [Haas, Peeters, 2006]. A high inflation rate may affect adversely the actual cost of raising debt capital, and this also should increase the speed of adjustment [Chipeta, Mbululu, 2013]. Hypothesis 9: the higher the inflation rate in a country, the higher the speed of adjustment of the capital structure to the target value as a result of share repurchase.
The interest rate level in an economy influences significantly the speed of adjustment: the higher the interest rate (the basis for measuring of which in the Russian economy is the key interest rate) is, the higher the cost of raising the debt capital, consequently, the speed of adjustment to the target capital structure is reduced when rates of an economy grow [Caglayan, Rashid, 2014]. Hypothesis 10: the higher the interest rates level in a country is, the lower the speed of adjustment of the capital structure to the target value as a result of share repurchase.

Institutional determinants and securities market development level also exert a great influence on the companies' speed of adjustment to the target capital structure. The following institutional factors influence the correlation of benefits and expenses caused by adjustment of the capital structure to the optimum value: ease of access to capital markets, maturity of the system of finance, protection of creditors' rights, property rights protection, information asymmetry between the company and investors or creditors [Öztekin, Flannery, 2012]. Many papers also study the influence of the relative maturity of the securities market on the attainment by the company of the target value. The paper [by Koerniadi et al., 2007] on the basis of a cross-country research revealed that the higher the maturity of the securities market, the smaller the deviation from the target capital structure after share repurchase because a high maturity of the securities market significantly facilitates access to financial resources for companies. The paper by Nivorozhkin [2005] revealed a positive dependence of the speed of adjustment to the target capital structure on such a level. Indeed, the practical experience of emerging economies shows that banks are often reluctant to grant loans to companies and claim high loan interest rates, and besides which the ability of banks to grant loans are limited to the banks' resources. Securities markets are also often limited by the amount of finance which the companies are able to raise. Access to funding in emerging markets is much lower than in mature economies, therefore raising funds to correct the capital structure on the basis of share repurchase may be difficult, therefore we state the following hypothesis. Hypothesis 11: the higher the maturity of securities market in the country is, the higher the speed of adjustment of the capital structure to the target value as a result of share repurchase.

\section{Research Model}

As we've shown in the first part of the paper a one-stage procedure of evaluation of the speed of adjustment does not make it possible to evaluate the influence of certain determinants on the speed of adjustment to the target capital structure, therefore we will use a two-stage evaluation method in the present paper. At the first stage we will define the target capital structure of the company on the basis of model (2). Using the obtained values of coefficients and values of determinants of the target capital structure we will evaluate the target value of the financial leverage of the capital structure $\widehat{L E V_{j, t}^{*}}$. Further, having 
obtained the above values we may calculate the value of deviation of the financial leverage from the optimum value $\widehat{D e v_{j, t}}$. using model (4). On the basis of the obtained value we will then get the following model specification, including in it a dummy variable of repurchase $\left(\right.$ Buyback $_{j t}$ ):

$$
L E V_{j, t}-L E V_{j, t-1}=\lambda_{j} \widehat{\operatorname{Dev}_{j, t}} * \text { Buyback }_{j t}+\varepsilon_{j, t}
$$

Insofar as the speed of adjustment may depend on dozens of factors (it is affected by financial results of the company which defined the value of the target capital structure itself, economic and institutional values), consequently, the speed of adjustment is a value defined by a certain list of determinants which in its turn helps to obtain the model specification to analyze the influence of various determinants on the speed of adjustment of a company to the target capital structure:

$$
\begin{aligned}
& L E V_{j, t}-L E V_{j, t-1}= \\
& =\left(\sum \beta_{i} Z_{j, t}\right) * \widehat{D e v_{j, t}} * \text { Buyback }_{j t}+\varepsilon_{j, t}
\end{aligned}
$$

In order to analyze the difference in the speed of adjustment for overleveraged companies and underleveraged companies we used the partial adjustment model with switching modes taking into consideration sre repurchase:

$$
\begin{aligned}
& L E V_{j, t}-L E V_{j, t-1}=\lambda_{1}\left(L E V_{j, t}^{*}-L E V_{j, t-1}\right) 1_{\left(q_{i t \leq c}\right)} * \\
& * \text { Buyback }_{j t}+\lambda_{2}\left(L E V_{j, t}^{*}-L E V_{j, t-1}\right) 1_{\left(q_{i t>c}\right)} * \\
& * \text { Buyback }_{j t}+\varepsilon_{j, t}
\end{aligned}
$$

where $1_{\left(q_{i t s c}\right)}$. is the indicator of the capital structure being below the target value; $\lambda_{1}$. is the speed of adjustment for the companies which capital structure is below the target value; $1_{\left(q_{i t>c}\right)}$. is the inditor of the capital structure being above the target value; $\lambda_{2}$. is the speed of adjustment for the companies with excessive debt load.

When evaluating the speed of adjustment of the capital structure to the target value of the financial leverage it is necessary to take into consideration potential benefits and expenses caused by a change of the leverage value: the more the benefit from approximation to the target value is, the higher the speed of adjustment should be. In this case one of the main factors defining the balance of benefits and expenses caused by change of the financial leverage value is the distance from the actl value to the optimum one (the direction in which it is necessary to optimize the capital structure), as well as the amount of the company cash flows. Following the methodology offered in article by [Faulkender M., Flannery M., Hankins K., Smith J., 2012, p. 637] the influence of the value of deviation from the target debt load and cash flows of the company on the speed of adjustment is studied using the following model:

$$
\begin{aligned}
& L E V_{j, t}-L E V_{j, t-1}=\left[\gamma_{1} \text { ExcessDev }_{j t}+\right. \\
& +\gamma_{2} \text { OverlapDev }{ }_{j t}+\gamma_{3} \text { OverlapCF } F_{j t}+ \\
& \left.+\gamma_{4} \text { ExcessCF }_{j t}\right] * \operatorname{Sin} g_{j t} * \text { Buyback }_{j t}+\varepsilon_{j t}
\end{aligned}
$$

where ExcessDev $=(|\operatorname{Dev}|-|C F|) *$ DevLarger is a part of the value of deviation of the actual valuof the financial leverage from the target one which is not covered by the company money flow; OverlapDev $=|C F|$ * DevLarger a part of deviation covered by the company money flow; Excess $C F=(|C F|-\mid$ Dev $\mid) *(1-$ DevLarger $)$ a part of the company money flow exceeding the value of deviation from the main leverage;

OverlapCF $=\mid$ Dev $\mid *(1-$ DevLarger $)$ the value of deviation from the target financial leverage when the company's money flow exceeds this value; Sing a dummy variable which equals - 1 for an overlevered company and 1 for underlevered companies; DevLarger - a dummy variable which equals 1 if the value of deviation of the actual capital structure value from the target value exceeds the company cash flows value $(|D e v|-|C F|)>0$, 0 - otherwise (i.e. if the value of deviation of thactual capital structure value from the target value is less or equals the company cash flows value

The first two criteria (ExcessDev и OverlapDev) assess the speed of adjustment to the target capital structure in s case where the company's money flow value is less than the discontinuity between the actual and target capital structure. A part of this deviation equaling the money flow value may be covered at a higher speed because the capital structure optimization expenses are less due to the use of the company's proprietary funds in case of a positive cash flow, or in view of the company's need in additional raising of debt capital in case of negative cash flows. In its turn the part of the deviation exceeding the cash flows value should be covered at a lower speed as long as the capital structure change expenses will be bigger.

The last two criteria (ExcessCF и OverlapCF ) describe the case when the company's money flow exceeds the value of deviation from the target capital structure. In this case the company is able to cover the whole discontinuity between the actual and target leverage, consequently the speed of adjustment should be significantly higher. In this case the value of the part of the money flow exceeding the discontinuity between the actual and target leverage should not influence the speed of adjustment as long as there is no need in the capital structure optimization. The variables of the research are described in table 1. 


\section{Table 1. Variables of the Research}

\begin{tabular}{|c|c|c|c|c|}
\hline Variable & Variable description & Designation & Calculation formula & Source of data \\
\hline Balance sheet leverage & Ratio of the company joint debt to the balance sheet value of its assets & BLEV & $\frac{\text { Total Debt }}{\text { Total Assets }}$ & Bloomberg \\
\hline Market leverage & $\begin{array}{l}\text { Ratio of the company joint debt to the total of its joint debt and market value of its joint- } \\
\text { stock capital }\end{array}$ & MLEV & $\frac{\text { Total Debt }}{\text { Market Capitalization }}$ & Bloomberg \\
\hline Company size & Napierian logarithm of the company total assets & Size & Ln(Total Assets) & Bloomberg \\
\hline Return on the company capital & Ratio of the company net profit to the total assets & ROA & $\frac{\text { Net Income }}{\text { Total Assets }}$ & Bloomberg \\
\hline Opportunities of growth of the company & Ratio of capital investments to the company total assets & Growth & $\frac{\text { Capital Expenditures }}{\text { Total Assets }}$ & Bloomberg. \\
\hline Share of the company tangible assets & Share of the company non-current assets to total assets & Tang & $\frac{\text { Property Plant and Equipment }}{\text { Total Assets }}$ & Bloomberg \\
\hline Amount of the company cash flows & $\begin{array}{l}\text { Ratio of operating income before interest, taxes and depreciation payment after deduction of } \\
\text { capital expenditures within the industry to total assets }\end{array}$ & $\mathrm{CF}$ & $\begin{array}{c}\frac{\text { EBITDA }- \text { Tax }- \text { Interest }}{\text { Total Assets }} \\
-\frac{\text { Cape }_{\text {industry }}}{\text { Total Assets }_{\text {industry }}}\end{array}$ & Bloomberg \\
\hline Level of the company business risk & Standard deviation of the operating income value to the company total assets & Risk & St.dev. $\left(\frac{\text { EBIT }}{\text { Total Assets }}\right)$ & Bloomberg \\
\hline Amount of repurchased shares & The amount of shares declared for repurchase to the total amount of outstanding shares & Share & $\frac{\text { Repurchased common shares }}{\text { Outstanding common shares }}$ & Bloomberg \\
\hline Economic growth & Annual GDP growth rate per capita expressed as a percentage & GDP & GDP per capita growth, annual \% & $\begin{array}{l}\text { Database of } \\
\text { World Bank }\end{array}$ \\
\hline Inflation rate & Consumer Price Index (CPI) expressed as a percentage & Inflation & CPI, annual \% & $\begin{array}{l}\text { Database of } \\
\text { World Bank }\end{array}$ \\
\hline Interest rate level & Average rate for loans countrywide & Lending & Lending interest rate, \% & $\begin{array}{l}\text { Database of } \\
\text { World Bank }\end{array}$ \\
\hline Stock market degree of maturity & Ratio of the total cost of the shares traded in the market to average market capitalization & Stock market & Stock market turnover ratio, \% & $\begin{array}{l}\text { Database of } \\
\text { World Bank }\end{array}$ \\
\hline
\end{tabular}

Source: prepared by the authors. 
Figure 2. Number of share repurchases in the period of 2005 to 2015

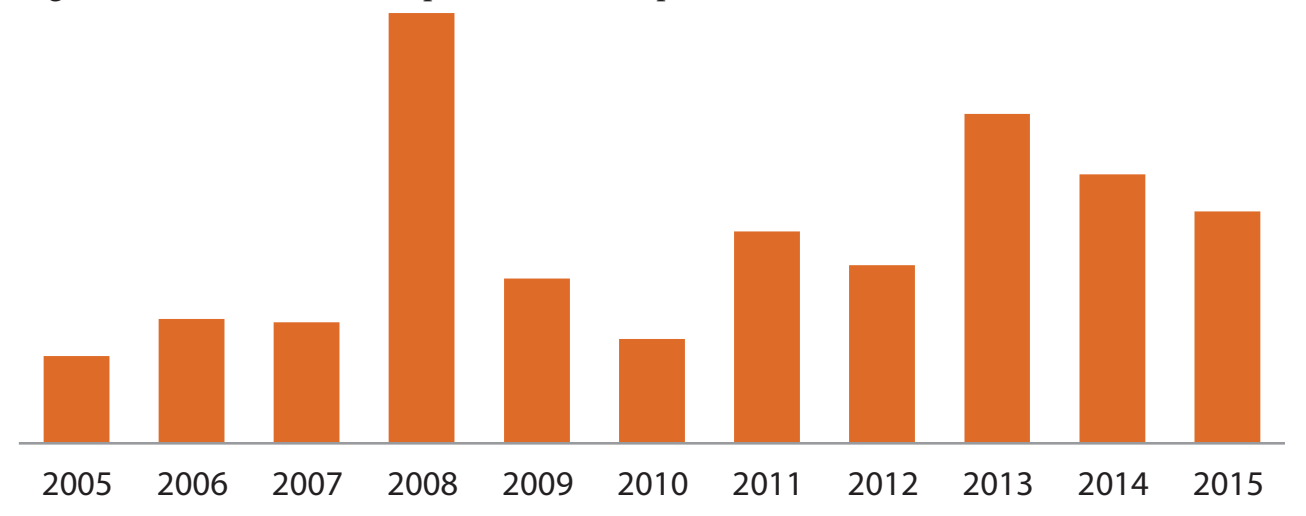

Source: on the basis of the authors' calculations.

\section{Description of the Companies Selection for the Research}

In order to carry out the research we made a selection of public companies from BRICS countries: Brazil, Russia, India, China, and RSA. The selection was made in several stages. At the first stage we made a selection of companies from BRICS countries (fig. 1) which repurchased shares in the period of 2000 to 2016 (371 companies). Then, we rejected 32 companies of the financial sector due to significant difference of their reporting structure from non-financial companies (the selection now consisted of 339 companies of non-financial sector). In order to ensure data comparability we rejected 64 companies from the selection of Russian companies which do not maintain records or do not publish records in publicly available sources in accordance with International Financial Reporting Standards. Consequently, the selection accounted for 275 companies.

Figure 1. Criteria of selection of companies for the research

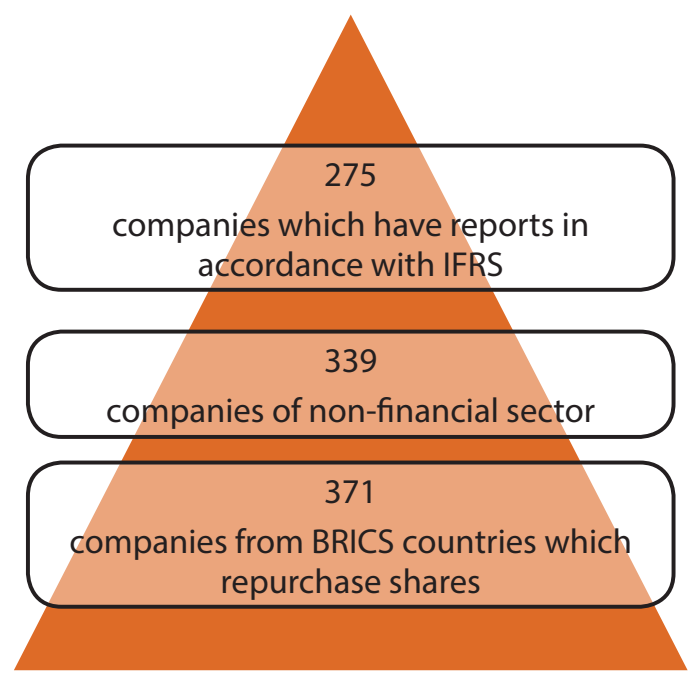

Source: on the basis of the authors' calculations.
From the point of view of repurchase characteristic features the following was included in the selection:

- Declared repurchase programs which have been completed;

- $\quad$ Share repurchase in the open market ${ }^{4}$;

- Share repurchase with known number of shares declared for repurchase.

While collecting data on the companies we identified a non-negligible omission of significant values in the period of 2000 to 2004 and in 2016. With that in mind, we decided to reduce the research period to 10 years. The data on the companies repurchasing their shares, dates of announcement of share repurchase, the share of repurchased stocks, and types of repurchase were developed on the basis of Bloomberg information. All financial indicators considered in this research were also taken from the Bloomberg database.Each value was represented in the database in millions of US dollars and was stated per calendar year in order to ensure data comparability. The macroeconomic data used in the research have been obtained from the database of the World Bank and indicate the percentage change of nominal GDP of each country in US dollars, the growth rate of consumer prices, the rate of borrowing and the stock market turnover ratio in each analyzed country.

Finally, we selected 670 repurchases carried out in the open market in various economic sectors in the period 2005 to 2015. See a breakdown of selected repurchases by years in fig. 2 below.

Fig. 3 represents a chart of allocation of share repurchase on a country-by-country basis. The number of companies on a country-by-country basis is irregular with an overwhelming majority of observations represented by Brazilian companies (320 out of 670). Allocation of the number of companies included in the selection on a country-by-country basis is more regular. In total the selection is comprised of data for 275 companies in the period of 2005 to 2015.

\footnotetext{
${ }^{4}$ As long as they account for the majority of share repurchases (over 90\%), and other types of repurchases are of specific character which is not taken into consideration by the development methodology of this research.
} 
Figure 3. Allocation of the number of share repurchases and number of companies on a country-by-country basis for the period of $2005-2015$

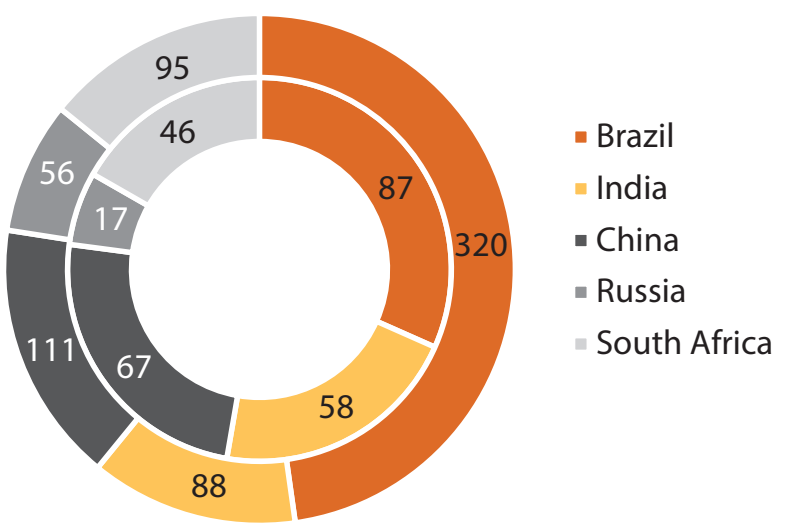

Source: on the basis of the authors' calculations.

Allocation of companies by sectors of the economy is regular (fig. 4), at the same time the basic amount of companies is concentrated in the basic sectors such as those involved in the manufacture of materials, goods of selective demand, and industry.
The average value of the balance sheet leverage for all studied selections amounted to approximately $26 \%$ of the total value of the company assets, which is approximately 11 percentage points less than the market leverage value (table 2).

Broken down by country, on average the balance sheet debt load in all countries is at a comparable level of $25-30 \%$ (table 3). However, a discontinuity in values is observed for the market leverage: a comparatively big debt load of companies from India, Brazil and Russia (40-45\%). Comparison of companies by financial indicators is also of special interest. Thus, Chinese and Brazilian companies are at average less profitable than in other BRICS countries, besides the opportunities for growth of companies in these countries are evaluated virtually at the same level as in other countries. The average size of a company in Russia is substantially bigger than in other BRICS countries, which indicates a strong concentration of the companies' market shares in the economy. Russia is also characterized by the biggest share of tangible assets in the general structure of the company assets.

Figure 4. Allocation of the number of companies on a sectoral basis in the period of $2005-2015$

\section{Energy engineering \\ Telecommunications \\ Industry}

First marketed consumer goods

Selective demand consumer goods

Immovable property

Materials

Utilities

Information technology

Health care

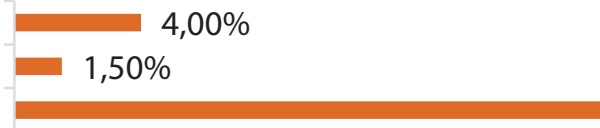

$11,60 \%$

$18,50 \%$

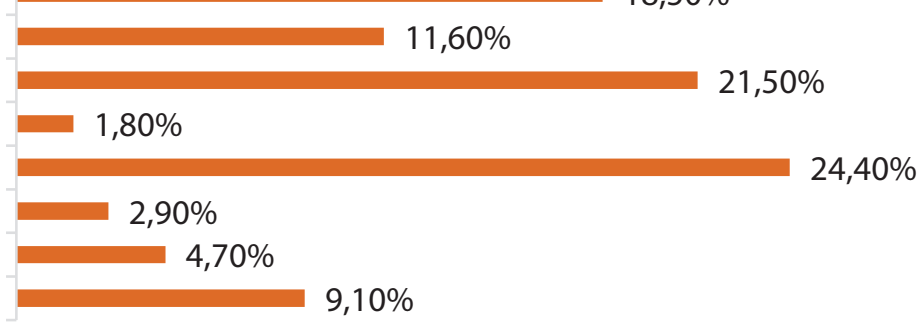

Source: on the basis of the authors' calculations.

Table 2. Descriptive statistics of values all through the studied selection

\begin{tabular}{|c|c|c|c|c|c|}
\hline Variable & Average & Median & Minimum & Maximum & Stand.deviation \\
\hline BLEV & 0.26 & 0.25 & - & 1.49 & 0.18 \\
\hline MLEV & 0.37 & 0.20 & - & 5.61 & 0.51 \\
\hline Size & 6.84 & 6.70 & -7.82 & 12.70 & 1.76 \\
\hline $\mathrm{ROA}$ & 6.89 & 5.97 & -72.08 & 120.81 & 9.00 \\
\hline Growth & 0.07 & 0.05 & - & 0.87 & 0.06 \\
\hline Tang & 0.52 & 0.52 & 0.01 & 0.99 & 0.20 \\
\hline Risk & 0.64 & 0.65 & 0.19 & 0.93 & 0.06 \\
\hline $\mathrm{CF}$ & 0.02 & 0.02 & -0.57 & 1.43 & 0.11 \\
\hline Share & 0.01 & - & - & 0.75 & 0.05 \\
\hline GDP & 4.49 & 4.46 & -7.85 & 13.64 & 4.11 \\
\hline Inflation & 5.82 & 5.66 & -0.70 & 15.53 & 2.89 \\
\hline Lending & 19.58 & 10.75 & 4.35 & 55.38 & 16.24 \\
\hline Stock market ratio & 89.42 & 69.07 & 22.19 & 290.97 & 66.82 \\
\hline
\end{tabular}

Source: on the basis of the authors' calculations. 
Table 3. Average value of indicators broken down by countries

\begin{tabular}{|c|c|c|c|c|c|}
\hline Variable & Brazil & China & India & Russia & South Africa \\
\hline BLEV & 0.29 & 0.26 & 0.25 & 0.30 & 0.20 \\
\hline MLEV & 0.45 & 0.29 & 0.40 & 0.45 & 0.24 \\
\hline Size & 7.14 & 6.74 & 6.03 & 8.77 & 6.72 \\
\hline ROA & 5.41 & 5.34 & 9.06 & 8.20 & 8.73 \\
\hline Growth & 0.06 & 0.07 & 0.08 & 0.10 & 0.06 \\
\hline Tang & 0.53 & 0.49 & 0.51 & 0.67 & 0.51 \\
\hline Risk & 0.64 & 0.67 & 0.63 & 0.61 & 0.62 \\
\hline $\mathrm{CF}$ & 0.03 & -0.01 & 0.01 & 0.05 & 0.04 \\
\hline Share & 0.01 & 0.01 & 0.01 & 0.01 & 0.01 \\
\hline GDP & 1.77 & 9.20 & 6.11 & 2.68 & 1.35 \\
\hline Inflation & 5.81 & 2.78 & 8.12 & 9.78 & 5.92 \\
\hline Lending & 42.33 & 5.83 & 10.92 & 11.22 & 10.58 \\
\hline Stock market ratio & 62.18 & 189.69 & 74.13 & 49.03 & 29.10 \\
\hline
\end{tabular}

Source: on the basis of the authors' calculations.

\section{Research Findings}

At the first stage we carried out the evaluation of the target capital structure of the studied companies. The following factors (for which significance has been proven in mature as well as in emerging markets in papers by [Booth et al., 2001; Bhaduri, 2002; Mitton, 2008]) were used as determinants of the target capital structure: share of the company tangible assets (Tang): the company size (Size), the company opportunities for growth (Growth), the company profitability $(R O A)$, degree of the company business risk (Risk), the company economic growth (GDP), inflation rate in the country (Inflation), as well as the interest rate level in the country as an indicator of credit availability (Lending). The results of the evaluation of model (2) are represented in table 4 . In order to avoid biased standard errors, all models have been evaluated using robust standard errors. The model based on the market financial leverage got a higher value of $R^{2}$-within which indicates a higher quality of the model. Consequently, we'll use the results of the evaluation based on the market financial leverage as the primary relevant evaluation model.

For the model evaluating the influence of factors on the market leverage the following were significant at the $1 \%$ level: the company indicators of return on capital, shares of tangible assets, economic growth and inflation rate in the country. At the 5\% level, the indicator of the company opportunities for growth was significant. At the $10 \%$ level, the business risk quotient was significant. The company size and interest rates levels do not exert a significant influence on the capital structure of the companies which repurchase shares in the open market.
Further, a new variable was obtained from each model after evaluation of regression - that of the target capital structure used for calculation of the speed of adjustment to the target capital structure when companies repurchase shares in the open market.

Determinants of the company and macroeconomic factors do not just define the target value of the financial leverage, but also influence how quickly the company can and will adjust to it. The results of evaluation of model (10) are presented in table 4 . The model based on the balance sheet financial leverage got a higher value of $R^{2}$-within which indicates a higher quality of the model, therefore we'll use as a basis the results of the evaluation focused on the balance sheet financial leverage. Considered overall, it may be noted that the indicators which express the company size, its profitability and interest rates levels show a multidirectional influence provided the leverage is measured on the basis of balance sheet or market indicators. As regards other indicators the direction of influence matches.

For the model evaluating the influence of factors on the balance sheet leverage the inflation rate in the country was significant at the $1 \%$ level. At the $5 \%$ level, the indicators of the company size, the company opportunities for growth and the amount of repurchased shares were significant. At the $10 \%$ level, the level of economic development in the country was significant. The companies' profitability, interest rates level and the maturity of the stock market do not exert a significant influence on the speed of adjustment of the companies which repurchase shares in the open market. 
Table 4. Results of evaluation of determinants of the target capital structure and speed of adjustment to it

\begin{tabular}{|c|c|c|c|c|}
\hline & \multicolumn{2}{|c|}{$\begin{array}{l}\text { Evaluation of determinants of the target } \\
\text { capital structure (model } 2 \text { ) }\end{array}$} & \multicolumn{2}{|c|}{$\begin{array}{l}\text { Evaluation of determinants of the } \\
\text { speed of adjustment (model 10) }\end{array}$} \\
\hline & BLEV & MLEV & BLEV & MLEV \\
\hline \multirow{2}{*}{ Const } & $0.1721^{\star}$ & $0.7160^{\star}$ & $0.0025^{\star * *}$ & $0.0101^{\star * *}$ \\
\hline & $(0.0951)$ & $(0.4119)$ & $(0.0002)$ & $(0.0015)$ \\
\hline \multirow[b]{2}{*}{ Share } & & & $3.0214^{\star *}$ & 5.1836 \\
\hline & & & $(0.5070)$ & $(1.2452)$ \\
\hline \multirow{2}{*}{ Size } & 0.0105 & 0.0082 & $0.0608^{\star *}$ & $-0.1067^{\star}$ \\
\hline & $(0.0074)$ & $(0.0218)$ & $(0.0283)$ & $(0.0548)$ \\
\hline \multirow{2}{*}{ Growth } & 0.1027 & $0.4431^{\star *}$ & $1.3318^{\star *}$ & 0.3482 \\
\hline & $(0.0633)$ & $(0.2236)$ & $(0.5847)$ & $(1.0887)$ \\
\hline \multirow{2}{*}{$R O A$} & $-0.0038^{\star \star *}$ & $-0.0118^{\star \star \star *}$ & 0.0010 & $-0.0099^{\star * \star}$ \\
\hline & $(0.0009)$ & $(0.0033)$ & $(0.0014)$ & $(0.0026)$ \\
\hline \multirow{2}{*}{ Tang } & $0.1638^{\star * \star}$ & $0.4337^{\star * *}$ & & \\
\hline & $(0.0535)$ & $(0.1441)$ & & \\
\hline \multirow{2}{*}{ Risk } & -0.0697 & $-0.8468^{\star}$ & & \\
\hline & $(0.1325)$ & $(0.5061)$ & & \\
\hline \multirow{2}{*}{$G D P$} & $0.0050^{*}$ & $0.0162^{\star * *}$ & $0.0820^{*}$ & $0.04981^{\star}$ \\
\hline & $(0.0011)$ & $(0.0043)$ & $(0.0172)$ & $(0.0266)$ \\
\hline \multirow{2}{*}{ Inflation } & $-0.0022^{\star *}$ & $-0.0186^{\star * *}$ & $-0.1063^{\star * *}$ & $-0.1015^{\star \star \star}$ \\
\hline & $(0.0011)$ & $(0.0036)$ & $(0.0194)$ & $(0.0294)$ \\
\hline \multirow{2}{*}{ Lending } & -0.0005 & -0.0006 & -0.0019 & $0.0145^{\star *}$ \\
\hline & $(0.0008)$ & $(0.0023)$ & $(0.0039)$ & $(0.0060)$ \\
\hline \multirow{2}{*}{ Stock market } & & & 0.01316 & $0.0024^{\star}$ \\
\hline & & & $(0.0009)$ & $(0.0012)$ \\
\hline$L S D V R^{2}$ & 0.72 & 0.73 & 0.58 & 0.44 \\
\hline Within $R^{2}$ & 0.56 & 0.59 & 0.36 & 0.26 \\
\hline$N$ & 3,025 & 3,025 & 2,750 & 2,750 \\
\hline
\end{tabular}

Note: results of evaluation using OLS with fixed effects of models (formula (2) and formula (10) correspondingly) by means of econometric package Gretl. In the brackets under the values of ratio the value of standard error is indicated, ${ }^{* *}$ corresponds to the level of significance of $1 \%,{ }^{* *}-5 \%,{ }^{*}-10 \%$.

Source: on the basis of the authors' calculations. 
Table 5. Results of Testing Models of Evaluation of the Speed of Adjustment

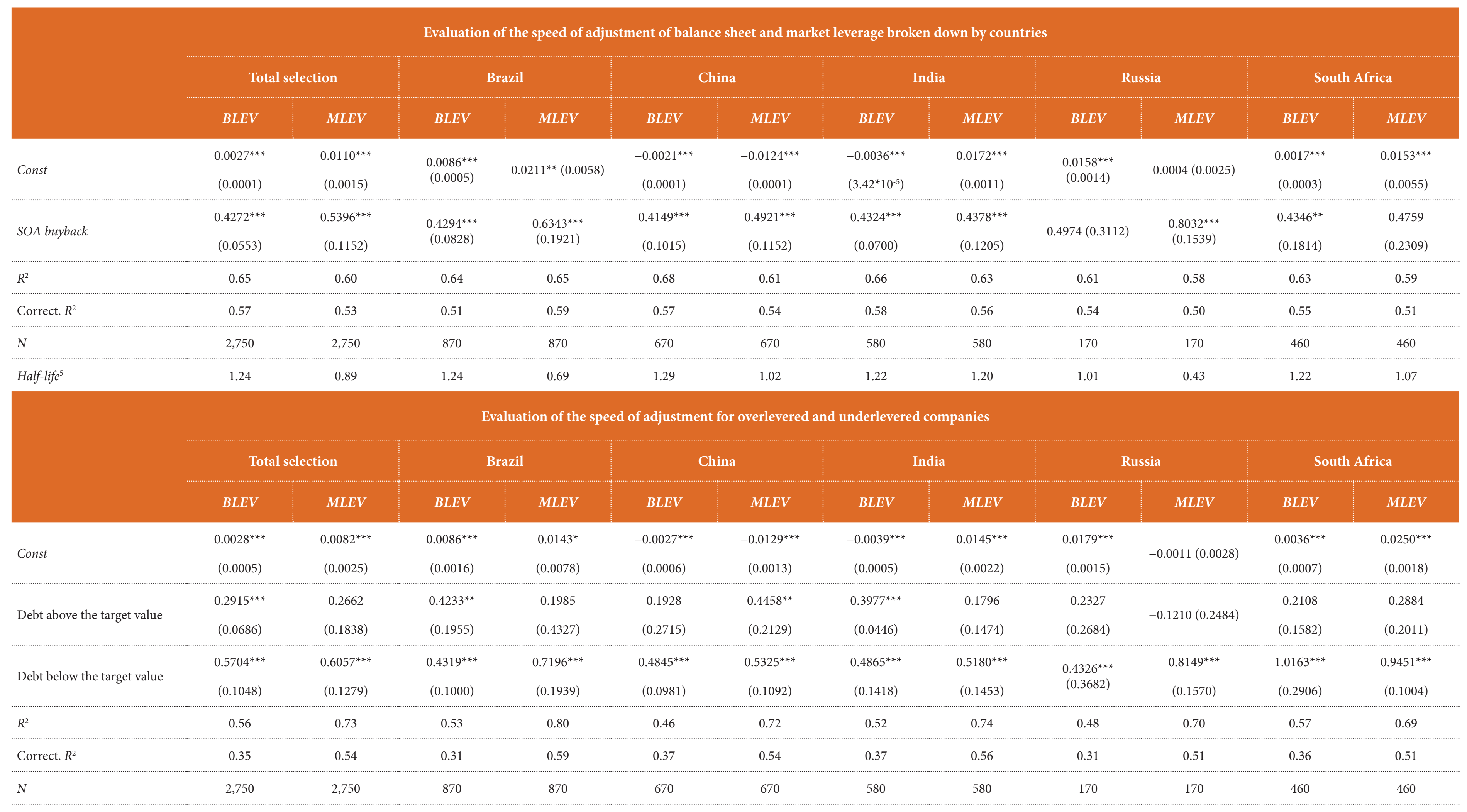

Note: results of evaluation using combined OLS. In the brackets under the values of ratio the value of standard error is indicated, ${ }^{* * *}$ corresponds to the level of significance of $1 \%,{ }^{* *}-5 \%$, $-10 \%$. Source: on the basis of the author' calculations. 
Hypothesis 2 on the influence of the size of repurchased shares on the speed of adjustment to the target capital structure was also confirmed. A large amount of shares repurchased at once results in significant reduction of the company owned capital and in a quicker correction of the capital structure against the target value. It should be noted that the ratio of the studied variable has the biggest values both in general in the selection and for the companies from Brazil, Russia and South Africa. Consequently, we can make a conclusion that in a share repurchase aiming at correction of the capital structure, the companies have to show consideration for the choice of the amount of repurchased shares.

Hypothesis 5 on the influence of the company size on the speed of adjustment while repurchasing shares in the open market was confirmed. Indeed, large companies have low financial imbalance costs and are more credit worthy in comparison with small companies. Consequently, investors trust them more and as a result they gain more opportunities to finance share repurchase (both using their own sources and using debt financing). For this very reason large companies will have higher values of speed of adjustment to the target capital structure. However, it should be noted that in Russia this factor adversely affects the company financial leverage. Consequently, large Russian companies are less motivated to correct the capital structure and do not use share repurchase to manage the capital structure.

Hypothesis 6 on the positive influence of the company opportunities for growth on the speed of adjustment to the target capital structure using share repurchase was confirmed: companies with great opportunities for growth due to an active financial policy (i.e. where they have access both to debt and joint-stock capital as they are more attractive for external investors) use more opportunities to finance share repurchase and, consequently, have higher values for speed of adjustment to the target capital structure.

Hypothesis 7 on the positive influence of the company profitability on the speed of adjustment was confirmed. More profitable companies may use both internal and borrowed sources to finance share repurchase and this results in a quicker correction of the capital structure towards the target value. Nevertheless, for Brazilian and Chinese companies the rate of return of the aggregate capital exerts a slight negative influence, and consequently, more profitable companies may disregard their bigger financial flexibility. While such a company has high profitability values the management is much less motivated to optimize the capital structure and reduce the cost of its raising. However, no sooner than profitability indicators decrease, a quicker optimization of the capital structure may become a more important source of improving the company effectiveness.

Further, we shall consider the results of the evaluation of the influence of macroeconomic factors and quality of maturity of the stock market on the speed of adjustment to the target capital structure as a result of share repurchase by companies in the open market. Hypothesis 8 on the positive influence of the country economic growth on the speed of adjustment was confirmed and hypothesis 9 on the positive influence of the inflation rate in the country on the companies' capital structure was not confirmed. Consequently, in the period of economic growth and low inflation, a company has more opportunities to finance share repurchase. In this situation, the company may use both its owned capital and debt capital (in the periods of economic upturn a lending boom is observed). This, in turn, results in higher values of the speed of adjustment. Hypothesis 10 on the negative influence of the rates of borrowing in the country on the company capital structure was also confirmed: when interest rates grow, credit availability in the country recedes, and consequently a lesser flexibility in the choice of financing for share repurchase is observed with the companies. This inhibits the speed of attaining the target value of the capital structure. It should be noted that this indicator turned out to be insignificant in general for the selection. Hypothesis 11 on the positive influence of the maturity level of the stock market of the country on the speed of adjustment to the target capital structure as a result of share repurchase in the open market was confirmed, however this indicator does not significantly influence the speed of adjustment.

As a result of the analysis of determinants of the speed of adjustment to the target capital structure using share repurchase, we may make a conclusion that all hypotheses were confirmed except for hypothesis 9 on the influence of the inflation rate in the country, and hypotheses 7, 10 and 11 were confirmed, subject to a proviso as regards degree of significance.

Then, we carried out evaluation of the speed of adjustment to the target capital structure using share repurchase in an open market, the test results are presented in table 5 .

In general, the obtained evaluations of the speed of adjustment indicate that as a result of share repurchase, the capital structure adjusts towards the target value. This is in line with the results of previous research (see fig. 5). Consequently, hypothesis 1 is confirmed and share repurchase may therefore be declared an efficient instrument for correction of the capital structure. Thus, for the whole selection of BRICS countries the speed of adjustment of the balance sheet leverage is approximately $43 \%$. As such, in one year companies may reduce the distance between the actual and target capital structure by $43 \%$ as a result of share repurchase. In a breakdown by country, one can observe that the results of evaluation of the speed of adjustment for the balance sheet leverage are approximately identical and amount to $43 \%$. However this indicator is the biggest for Russian companies - $50 \%$, (i.e. Russian companies eliminate a half of deviation from the target capital structure in 1.01 year - this value is indicated in the line Half-life for other countries, table 5). Apart from that, for Russian companies the value of the speed of adjustment for balance sheet values turned out to be insignificant. Probably there exist significant deviations in the speed of adjustment depending on the direction of the deviation from the target capital structure. 
Figure 5. Evaluation of the Speed of Adjustment Broken down by Countries

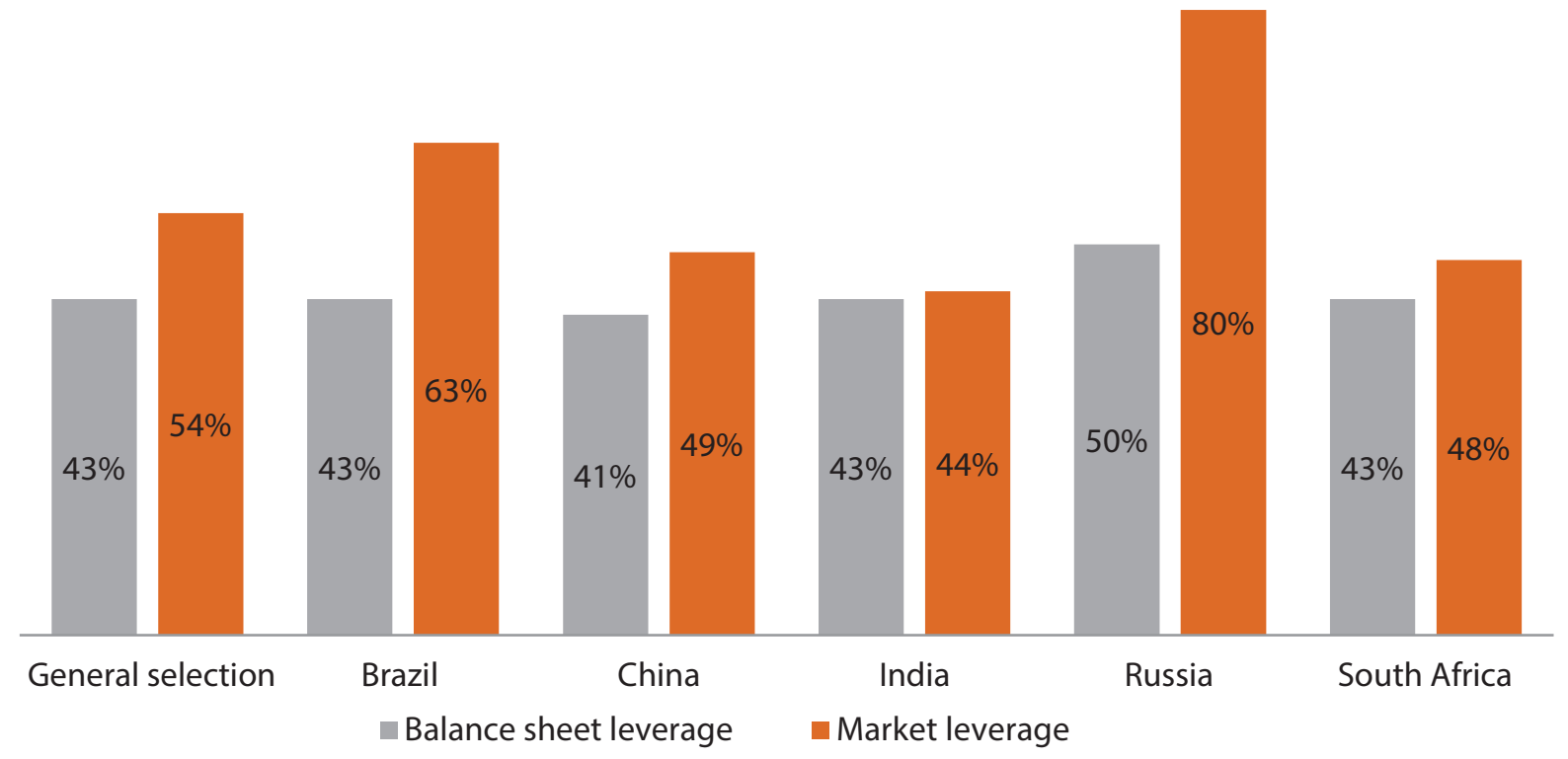

Source: on the basis of the authors' calculations.

Figure 6. Evaluation of the Speed of Adjustment of the Balance Sheet Leverage

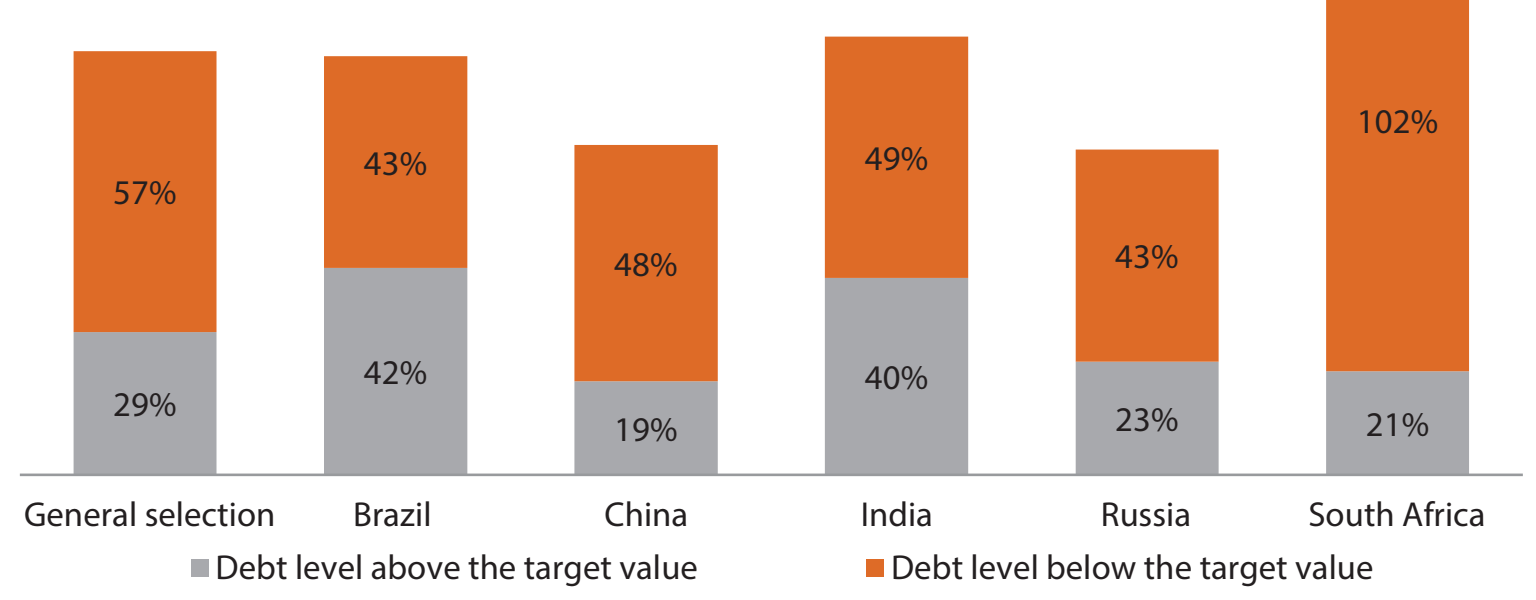

Source: on the basis of the authors' calculations.

It should be noted that speeds of adjustment for the market leverage showed bigger values in comparison with the balance sheet leverage: in general, for the BRICS countries' companies the speed of adjustment amounted to $54 \%$, consequently, the companies eliminate a half of the discontinuity in 0.89 years. Apart from that, companies from Russia and Brazil show the higher speed of adjustment (within 63-80\%). It indicates that the companies are able to approximate the target structure in a very short period. Other countries also show rather quick rates of the speed of adjustment in the range of 44 to $49 \%$ which correspond to the evaluation of the speed of adjustment for the balance sheet leverage.

Results of evaluation of the mode switching partial adjustment model taking into consideration share repurchase (model 11) are represented in fig. 6 for the balance sheet financial leverage and in fig. 7 - for the market leverage. In general, the results obtained indicate that underleveraged companies approximate the optimum capital structure significantly quicker than companies with excessive debt load: the speed of adjustment of the balance sheet values of the leverage for the companies with an excessive debt load on average amounts to $29 \%$, market values - 27\%, (and this, as you can see by fig. 6 and 7 , is almost twice as slow as for the companies with an insufficient amount of debt). Consequently, hypothesis 3, that companies with an excessive debt load adjust to the target capital structure when repurchasing shares more slowly, is confirmed. The biggest differences in the speed of adjustment are observed for Chinese and South African companies when the balance sheet leverage model is evaluated. When evaluating the market leverage model 
the biggest differences in the speed of adjustment depending on the deviation from the target capital structure are observed for Brazil, India and South Africa.

After evaluation of the mode switching partial adjustment model, the differentiating conclusions as regards Russian and South Africa companies consist in the fact that for them the value of the speed of adjustment is significant as regards the underleveraged companies while in general all through the selection of companies from the abovementioned countries the speed is not significant.
Consequently, the obtained result may be explained by the fact that companies are able to increase the debt load rather easily while the debt level is below the target value, because in this case share repurchase exerts a greater influence on the capital structure, and thus the companies are able to increase the debt up to the target value at a rather high speed. For Brazil, India and China the speed of adjustment is significant both for underleveraged companies and for overleveraged companies.

Figure 7. Evaluation of the Speed of Adjustment of the Market Leverage

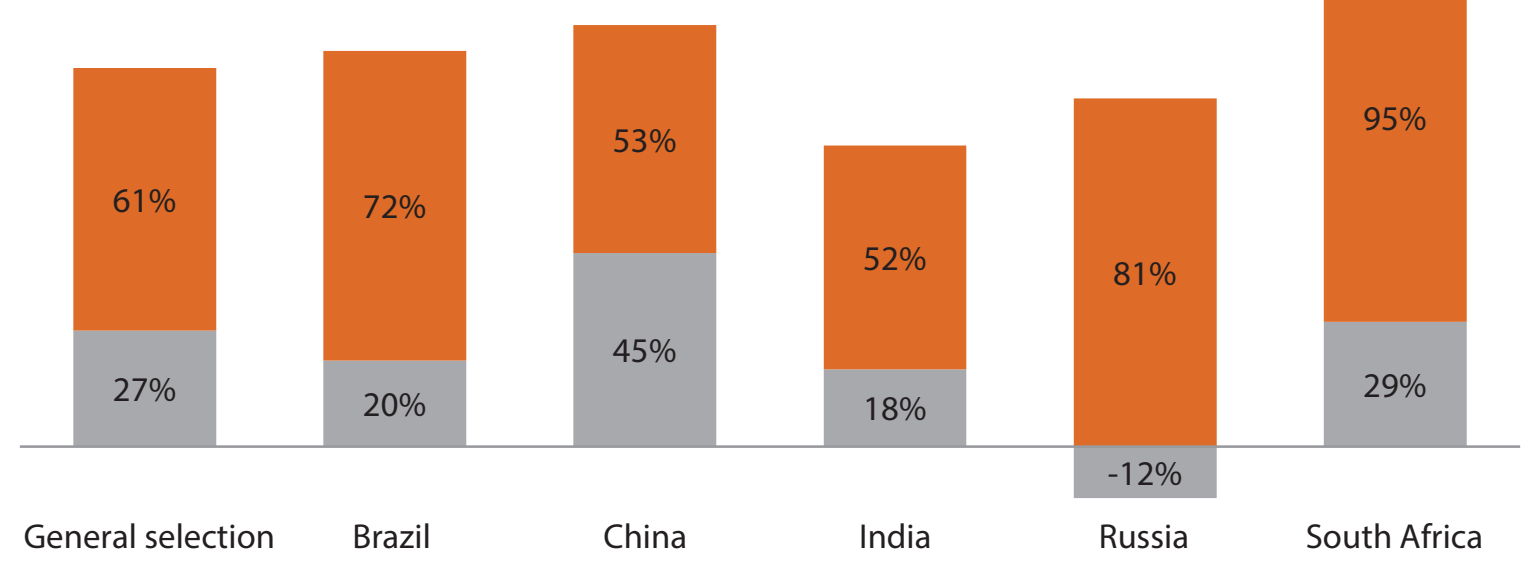

Debt level above the target value

- Debt level below the target value

Source: on the basis of the authors' calculations.

At the same time evaluation of the model for Russian companies demonstrates controversial results: the companies with an excessive level of debt load do not approximate the target capital structure, but on the contrary, move away from it (the debt value increases against the target value), and this contradicts the hypothesis on the companies' striving to optimize the capital structure. It should be noted that this effect was observed only for thos companies with an excessive debt value.

Thus, the companies in BRICS countries are prone to adjust quicker to the target capital structure when the financial leverage is below the target value while companies with an excessive debt load perform optimization much more slowly. Apart from that, the decision on share repurchase in order to optimize the financial leverage is taken in accordance with the evaluated benefits and costs caused by such adjustment:

- if the current capital structure of the company is close to the target one the company benefits from share repurchase may be significantly less than both the costs which include commission fees for share repurchase and transaction costs;

- if a deviation from the optimum capital structure is rather great the company benefits will be significantly greater, which means that the speed should be higher.
Apart from that, the company money flow influences significantly the costs of adjustment;

- if a company has great positive cash flows the latters may become a moderately priced source of share repurchase which in its turn reduces significantly the costs of the financial leverage optimization;

- in the case of negative cash flows a company faces the necessity of their financing.

Therefore, it is of great importance to study the influence of the ratio of the deviation value to cash flows of the company on speed of adjustment to the target capital structure.

The results of the evaluation of the partial adjustment model taking into consideration the value of deviation of the capital structure from the target value and the amount of cash flows of the company (model 12) are represented in table 6 . For the model on the basis of the balance sheet financial leverage a higher value of corrected determination coefficient for the debt value above the target value and on the basis of the market leverage for the capital structure below the target value was obtained. Therefore, we'll use as a basis for the debt level above the target value the results on the basis of the balance sheet financial leverage and for the debt value below the target value - the results on the basis of the market leverage. 
If the existing capital structure exceeds the target value and the company does not have sufficient cash flows to eliminate the discontinuity in the capital structure (case Overlap $\mid$ Dev $|>| C F \mid$ and ExcessDev) the company does not approximate the target capital structure as a result of share repurchase, but on the contrary, moves away from it (the debt value increases): the total speed of adjustment in this case amounts approximately to $-20 \%$. However if the company has a significant value of cash flows which exceed the value of deviation from the target capital structure (case Overlap $|C F|>|D e v|$ and ExcessCF) as a result of share repurchase, a significant adjustment to the target value takes place The fastest actors re: the speed of adjustment are those companies within the deviation amount from the target value and those for whom, at attaining the target value, the company's capital structure shows practically no changes. On the other hand, if the real capital structure of the company is below the target value then, as a result of repurchase, the speed of adjustment achieves high values in both cases: approximately $56 \%$ in case of a small value of the company money flow and $65 \%$ in case the money flow in excess of the value of deviation of the capital structure from the target value. Consequently, in this case share repurchase is advantageous for companies with any value of their cash flows.

Table 6. Evaluation of the influence of the value of deviation of the leverage from the target value and sufficiency of money flow aimed to cover it on the speed of adjustment to the target capital structure of the companies from BRICS countries

\begin{tabular}{|c|c|c|c|c|}
\hline & \multicolumn{2}{|c|}{ Balance sheet leverage, $B L E V$} & \multicolumn{2}{|c|}{ Market leverage, MLEV } \\
\hline & $\begin{array}{c}\text { Debt above the target } \\
\text { value }\end{array}$ & $\begin{array}{c}\text { Debt below the target } \\
\text { value }\end{array}$ & $\begin{array}{c}\text { Debt above the target } \\
\text { value }\end{array}$ & $\begin{array}{c}\text { Debt below the target } \\
\text { value }\end{array}$ \\
\hline \multirow{2}{*}{ Const } & $-0.0287^{\star * \star}$ & $0.03062^{\star * \star}$ & $-0.0954^{\star * \star}$ & $0.0778^{\star * *}$ \\
\hline & $(0.0025)$ & $(0.0021)$ & $(0.0126)$ & $(0.0073)$ \\
\hline \multirow{2}{*}{ ExcessDev } & $-0.5651^{* *}$ & $0.2298^{* *}$ & -0.1317 & $0.5439^{* * *}$ \\
\hline & $(0.2308)$ & $(0.1038)$ & $(0.1803)$ & $(0.1597)$ \\
\hline \multirow{2}{*}{$\begin{array}{l}\text { Overlap } \\
\mid \text { Dev }|>| C F \mid\end{array}$} & 0.3939 & 0.2359 & 1.1958 & 0.5859 \\
\hline & $(0.3117)$ & $(0.1439)$ & $(0.7761)$ & $(0.3974)$ \\
\hline \multirow{2}{*}{$\begin{array}{l}\text { Overlap } \\
|C F|>\mid \text { Dev } \mid\end{array}$} & $0.6049^{* * *}$ & $0.1817^{\star * *}$ & $1.5133^{* *}$ & $0.6455^{* *}$ \\
\hline & $(0.2060)$ & $(0.1650)$ & $(0.7576)$ & $(0.3036)$ \\
\hline \multirow{2}{*}{ ExcessCF } & 0.1519 & -0.0273 & 0.2287 & -0.1571 \\
\hline & $(0.0428)$ & $(0.0659)$ & $(0.3556)$ & $(0.1121)$ \\
\hline$R^{2}$ & 0.73 & 0.58 & 0.65 & 0.70 \\
\hline Correct. $R^{2}$ & 0.55 & 0.46 & 0.49 & 0.50 \\
\hline$N$ & 1,276 & 1,474 & 1,118 & 1,907 \\
\hline
\end{tabular}

Note: results of evaluation using combined OLS. In the brackets under the values of ratio the value of standard error is indicated, ${ }^{* *}$ corresponds to the level of significance in $1 \%,{ }^{\star *}-5 \%,{ }^{\star}-10 \%$.

Source: on the basis of the authors' calculations.

On the basis of the results of the evaluation of the model we can make a conclusion that the money flow of companies from BRICS countries exerts a significant influence on the speed of adjustment as a result of share repurchase. When the value of discontinuity of the existing leverage against the target value exceeds the absolute value of money flow (i.e. when $|D e v|-|C F|>0$ ) the companies strive to cover the discontinuity value quicker within the amount of their money flow and the rest amount is covered at a much slower speed. At the same time the companies with the money flow exceeding the value of deviation of the capital structure from the target value have the biggest values of the speed of adjustment as a result of share repurchase, consequently hypothesis 4 is confirmed. It is important to note that for the companies with the existing capital structure above the target value share repurchase is an effective instrument for correction of the capital structure only in case of existence of significant money flow in the company.

The main results obtained at all stages of the empiric study are represented in fig. 8 . 
Figure 8. Results of the Empirical Study

\begin{tabular}{|c|c|c|}
\hline $\begin{array}{l}\text { The most significant determinants } \\
\text { of the target capital structure }\end{array}$ & $\begin{array}{l}\text { Evaluation of the speed of } \\
\text { adjustment as a result of share } \\
\text { repurchase }\end{array}$ & $\begin{array}{l}\text { The most significant determinants } \\
\text { of the speed of adjustment of the } \\
\text { capital structure when repurchasing } \\
\text { shares }\end{array}$ \\
\hline $\begin{array}{l}\text { - Return on capital of the company } \\
\text { Opportunities for growth of the } \\
\text { company } \\
\text { - Share of the company tangible } \\
\text { assets } \\
\text { Degree of the company business } \\
\text { risk } \\
\text { Economic growth } \\
\text { Inflation rate }\end{array}$ & $\begin{array}{l}\text { Speed of adjustment - } 41-50 \% \\
\text { for balance sheet values; } 44-80 \% \\
\text { for market values of the leverage } \\
\text { Speed of adjustment is higher } \\
\text { when the financial leverage is } \\
\text { below the target value } \\
\text { Companies with money flow } \\
\text { above the discontinuity value } \\
\text { in the capital structure have the } \\
\text { highest speed of adjustment }\end{array}$ & $\begin{array}{ll}\text { - } & \text { Company size } \\
\text { - } & \text { Company opportunities for } \\
\text { growth } \\
\text { - } & \text { Share of repurchased stocks } \\
\text { - } & \text { Economic growth } \\
\text { - } & \text { Inflation rate }\end{array}$ \\
\hline
\end{tabular}

Source: on the basis of the authors' calculations.

\section{Algorithm of attainment of the Target Capital Structure using Share Repurchase}

On the basis of the undertaken research we can offer the algorithm which would help the companies in practice to manage the capital structure efficiently using share repurchase. The offered algorithm is divided into the following stages:

1) Defining the company need in change of the existing Capital Structure in accordance with its current short-term and long-term objectives.

2) Analysis of the company internal characteristics and the state of external economic environment. On the basis of the undertaken research we have found out that for major companies with great opportunities for growth, share repurchase is the most profitable instrument of capital structure correction. However, if the company is not large enough but at the same time it has high opportunities for growth (for example, IT companies) share repurchase may also be a very effective instrument. Apart from that, it is necessary to assess the current macroeconomic status: if in the current period high rates of growth and low rates of inflation are typical of the country it is a favorable moment to carry out the share repurchase procedure in order to correct the capital structure.

3) Analysis of the current state of the Capital Structure. It is necessary to calculate the target value of the capital structure by formula (2) or to use an industry average value or the value of the financial leverage of the industry leader:

- if the current capital structure of the company is above the target value, then in accordance with the undertaken research the speed of adjustment of the capital structure to the target value in general is not high (approximately 26\%). A significant influence on the speed of adjustment in this case is exerted by the amount of cash flows of the company: if the company has significant cash flows exceeding the deviation of the actual capital structure from the target value in this case the speed of adjustment may attain $60 \%$;

- if the current capital structure of the company is below the target value then in accordance with the undertaken research this state is favorable for correction of the capital structure using share repurchase: the speed of adjustment may attain $61 \%$ during a period.

4) Calculation and comparison of prospective costs and benefits from Share Repurchase:

- if the current capital structure of the company is close to the target value the benefits from share repurchase in order to optimize the capital structure may be less than the costs incurred by the repurchase;

- if the company is significantly far from the target value the benefits from optimization are more than costs, and consequently share repurchase is justified from the point of view of the capital structure management policy.

5) Defining characteristic features of Share Repurchase:

- amount and form of repurchase. It a company intends to significantly alter the capital structure it has to repurchase a large amount of shares. For these purposes the following forms of repurchase will suit: purchase of a fixed number of shares at a fixed price, share repurchase using the Dutch auction, and direct agreement with shareholders. Alongside this, from the point of view of transaction costs, share repurchase in an open market is the least expensive option because it does not necessitate negotiations or a search for the best offers. Consequently, if the 
prospective expenses from share repurchase are critical for the company in this case we recommend repurchasing shares in an open market;

- financing method. If a company has high positive cash flows they may be a moderately priced source of share repurchase, thus reducing the costs of the financial leverage optimization significantly. If the company has chosen debt financing to carry out share repurchase the management has to evaluate the financial status of the company after the repurchase more thoroughly as long as high values of the financial leverage increase the risk of the company insolvency, and this may affect adversely the company goodwill and to cause reduction of price for shares as well as.

6) Share repurchase and correction of the Capital Structure.

7) Analysis of the effectiveness of correction of the Capital Structure using Share Repurchase. As long as we presume that attainment by the company of the target capital structure within share repurchase is important to financial management, it is necessary for an evaluation of effectiveness to define the value of deviation of the actual capital structure after share repurchase from the target value and to compare to a similar value before the repurchase procedure. If the discontinuity has shortened we can consider that the correction has succeeded. In this case, it is reasonable to evaluate the company solvency indicators in order to make sure that the company financial status has not become worse as a result of share repurchase.

Thus, implementation of this algorithm will help to ensure a maximally successful and profitable share repurchase for the companies which set as their objective the correction of the capital structure towards the target value.

\section{Conclusion}

The capital structure is one of the key parameters of company management. An efficient policy of capital structure management helps the company to increase its value. Share repurchase is a phenomenon which has not been studied entirely as regards its influence on the capital structure. As such, the companies engaged in share repurchase should understand the consequences of this remedy including the consequences for the shareholders' welfare. That is why this subject is of relevance both from the point of view of science and practice.

In this paper, on the basis of a selection of public companies from BRICS countries in the period of 2005 to 2015 using 670 cases of share repurchase, we obtained the following new results. First, it was confirmed that as a result of share repurchase by companies correction of the actual capital structure towards the target value takes place (on average, in the selection the speed of adjustment amounts to $43 \%$, and for Russian companies the speed of adjustment is higher and amounts to approximately 50\%).
Second, the nature of deviation of the capital structure from the target value significantly influences the speed of adjustment: underleveraged companies approximate the target capital structure at a significantly higher speed than companies with an excessive debt load (29 against 57\%). Third, the amount of the company money flow influences significantly the speed of adjustment: if the existing capital structure of the company exceeds the target value the speed of adjustment of the capital structure to the target value as a result of share repurchase is rather low (approximately 26\%) but if the company has significant cash flows exceeding the deviation of the actual capital structure from the target value in such case the speed of adjustment may attain $60 \%$. However, if the current capital structure of the company is below the target value, the speed of adjustment attains high values in both cases: approximately $56 \%$ in case of a small money flow of the company and $65 \%$ when the money flow exceeds the value of deviation of the capital structure for the period (in our case - one year). It should be noted that in earlier studies there were no conclusions on such dependencies.

The algorithm offered by the authors, which has been developed on the basis of the research results, should help companies to more effectively manage capital structure in practice using share repurchase. Management of the company capital structure is a complex and multiple-stage procedure. In order to make the company achieve the best results during the share repurchase a thorough analysis of both the exterior macroeconomic environment and inner characteristics of the company itself is necessary.

\section{References}

1. Federal law "On joint stock companies" of 26.12.1995 No. 208-FZ. Adopted by the State Duma on November 24, 1995 (the latest version). URL: http://www.consultant.ru/ document/cons_doc_LAW_8743/(In Russ.).

2. World Bank database. URL: http://databank.worldbank. org/data/home.aspx

3. Kokoreva M.S., Yulova S.M. The influence of internal and institutional factors on the speed of adjustment to the target capital structure in developed and emerging markets. Korporativnye finansy = Journal of Corporate Finance Research. 2013;7(4):4-18. (In Russ.).

4. Petrova Yu. Sometimes they come back. Kommersant Sekret Firmy. 2008. URL: https://www.kommersant.ru/ doc/856368. (In Russ.).

5. Shakhina N.A., Kokoreva M.S. Empirical testing of dynamic capital structure choice: Case of Russian companies. Korporativnye finansy = Journal of Corporate Finance Research. 2010;4(4):31-40. (In Russ.).

6. Anderson R., Reeb D. Founding family ownership, corporate diversification, and firm leverage. The Journal of Law \& Economics. 2003;46(2):653-684. DOI: $10.1086 / 377115$ 
7. Andriosopoulos D., Hoque H. The determinants of share repurchases in Europe. International Review of Financial Analysis. 2013;27(C):65-76. DOI: 10.1016/j. irfa.2012.12.003

8. Aren S., Alpkan L., Sezen B., Guncu Z.A. Drivers of firms' debt ratios: Evidence from Taiwanese and Turkish firms. Journal of Business Economics and Management. 2012;13(1):53-70. DOI: 10.3846/16111699.2011.620142

9. Aybar-Arias C., Casino-Martínez A., López-Gracia J. On the adjustment speed of SMEs to their optimal capital structure. Small Business Economics. 2012;39(4):977-996. DOI: $10.1007 / \mathrm{s} 11187-011-9327-6$

10. Bargeron L., Kulchania M., Thomas S. Accelerated share repurchases. Journal of Financial Economics. 2011;101(1):69-89. DOI: 10.1016/j.jfineco.2011.02.004

11. Bhaduri S. Determinants of capital structure choice: a study of the Indian corporate sector. Applied Financial Economics. 2002;12(9):655-665. DOI: 10.1080/09603100010017705

12. Bonaimé A. Repurchases, reputation, and returns. Journal of Financial and Quantitative Analysis. 2012;47(2):469-491. DOI: 10.1017/S0022109012000087

13. Bonaimé A., Öztekin Ö., Warr R. Capital structure, equity mispricing, and stock repurchases. Journal of Corporate Finance. 2014;26(C):182-200. DOI: 10.1016/j. jcorpfin.2014.03.007

14. Booth L., Aivazian V., Demirguc-Kunt A., Maksimovic V. Capital structures in developing countries. The Journal of Finance. 2001;56(1):87-130. DOI: 10.1111/00221082.00320

15. Caglayan M., Rashid A. The response of firms' leverage to risk: Evidence from UK public versus nonpublic manufacturing firms. Economic Inquiry. 2014;52(1):341363. DOI: $10.1111 /$ ecin. 12042

16. Castro P., Tascón Fernández M.T., Amor-Tapia B., de Miguel A. Target leverage and speed of adjustment along the life cycle of European listed firms. BRQ Business Research Quarterly. 2016;19(3):188-205. DOI: 10.1016/j. brq.2016.01.003

17. Chakraborty I. Capital structure in an emerging stock market: The case of India. Research in International Business and Finance. 2010;24(3):295-314. DOI: 10.1016/j. ribaf.2010.02.001

18. Chen J., Strange R. The determinants of capital structure: Evidence from Chinese listed companies. Economic Change and Restructuring. 2005;38(1):11-35. DOI 10.1007/s10644-005-4521-7

19. Chipeta C., Mbululu D. Firm heterogeneity, macroeconomic conditions and capital structure adjustment speeds: Evidence from the JSE. Investment Analysts Journal. 2013;42(77):69-80. DOI: 10.1080/10293523.2013.11082557
20. Cook D.O., Tang T. Macroeconomic conditions and capital structure adjustment speed. Journal of Corporate Finance. 2010;16(1):73-87. DOI:10.1016/j. jcorpfin.2009.02.003

21. Dang V.A., Kim M., Shin Y. Asymmetric adjustment toward optimal capital structure: Evidence from a crisis. International Review of Financial Analysis. 2014;33:226242. DOI: $10.1016 /$ j.irfa.2014.02.013

22. Dang V.A., Kim M., Shin Y. Asymmetric capital structure adjustments: New evidence from dynamic panel threshold models. Journal of Empirical Finance. 2012;19(4):465-482. DOI: 10.1016/j.jempfin.2012.04.004

23. DeAngelo H., DeAngelo L., Whited T.M. Capital structure dynamics and transitory debt. Journal of Financial Economics. 2011;99(2):235-261. DOI:10.1016/j. jfineco.2010.09.005

24. Dittmar A.K. Why do firms repurchase stock? The Journal of Business. 2000;73(3):331-355. DOI: $10.1086 / 209646$

25. Drobetz W., Wanzenried G. What determines the speed of adjustment to the target capital structure? Applied Financial Economics. 2006;16(13):941-958. DOI: 10.1080/09603100500426358

26. Faulkender M., Flannery M.J., Hankins K.W., Smith J.M. Cash flows and leverage adjustments. Journal of Financial Economics. 2012;103(3):632-646. DOI: 10.1016/j.jfineco.2011.10.013

27. Graham J.R., Leary M.T., Roberts M.R. A century of capital structure: The leveraging of corporate America. Journal of Financial Economics. 2015;118(3):658-683. DOI: 10.1016/j.jfineco.2014.08.005

28. Haas R., Peeters M. The dynamic adjustment towards target capital structures of firms in transition economies. Economics of Transportation. 2006;14(1):133-169. DOI: 10.1111/j.1468-0351.2006.00237.x

29. Hall G.C., Hutchinson P.J., Michaelas N. Determinants of the capital structures of European SMEs. Journal of Business Finance \& Accounting. 2004;31(5-6):711-728. DOI: 10.1111/j.0306-686X.2004.00554.x

30. Haron R., Khairunisah I., Nor F. Factors affecting speed of adjustment to target leverage: Malaysia evidence. Global Business Review. 2013;14(2):243-262. DOI: 10.1177/0972150913477469

31. Ikenberry D., Lakonishok J., Vermaelen T. Stock repurchases in Canada: Performance and strategic trading. The Journal of Finance. 2000;55(5):2373-2397. DOI: $10.1111 / 0022-1082.00291$

32. Koerniadi H., Liu M.-H., Tourani-Rad A. Share repurchases in New Zealand. In: Issues in corporate governance and finance. Jordan Hill: JAI Press Publ.; 2007:481-498. (Advances in Financial Economics. Vol. 12). 
33. Komera S., Lukose P.J.J. Heterogeneity and asymmetry in speed of leverage adjustment: The Indian experience. Review of Pacific Basin Financial Markets and Policies. 2016;19(03):165-191. DOI: 10.1142/S0219091516500193

34. Lemma T.T., Negash M. Determinants of the adjustment speed of capital structure: evidence from developing economies. Journal of Applied Accounting Research. 2014;15(1):64-99. DOI: 10.1108/JAAR-03-20120023

35. McMillan D.G., Camara O. Dynamic capital structure adjustment: US MNCs \& DCs. Journal of Multinational Financial Management. 2012;22(5):278-301. DOI: 10.1016/j.mulfin.2012.10.001

36. Mitton T. Why have debt ratios increased for firms in emerging markets? European Financial Management. 2008;14(1):127-151. DOI: 10.1111/j.1468036X.2007.00430.x

37. Mukherjee S., Mahakud J. Dynamic adjustment towards target capital structure: Evidence from Indian companies. Journal of Advances in Management Research. 2010;7(2):250-266. DOI: 10.1108/09727981011085020

38. Nivorozhkin E. Financing choices of firms in EU accession countries. Emerging Markets Review. 2005;6(2):138-169. DOI: 10.1016/j.ememar.2004.10.002

39. Noulas A., Genimakis G. The determinants of capital structure choice: Evidence from Greek listed companies. Applied Financial Economics. 2011;21(6):379-387. DOI: 10.1080/09603107.2010.532108

40. Öztekin Ö., Flannery M.J. Institutional determinants of capital structure adjustment speeds. Journal of Financial Economics. 2012;103(1):88-112. DOI: 10.1016/j. jfineco.2011.08.014

41. Pandey A., Singh M. Capital structure determinants: A literature review. African Journal of Accounting, Auditing and Finance. 2015;4(2):163-176. DOI: 10.1504/ AJAAF.2015.072226
42. Panno A. An empirical investigation on the determinants of capital structure: The UK and Italian experience. Applied Financial Economics. 2003;13(2):97112. DOI: $10.1080 / 09603100210100882$

43. Qian Y., Tian Y., Wirjanto T.S. Do Chinese publicly listed companies adjust their capital structure toward a target level? China Economic Review. 2009;20(4):662-676. DOI: 10.1016/j.chieco.2009.06.001

44. Rajan R.G., Zingales L. What do we know about capital structure? Some evidence from international data. The Journal of Finance. 1995;50(5):1421-1460. DOI: $10.2307 / 2329322$

45. Shyam-Sunder L., Myers S.C. Testing static tradeoff against pecking order models of capital structure. Journal of Financial Economics. 1999;51(2):219-244. DOI: 10.1016/S0304-405X(98)00051-8

46. Titman S., Wessels R. The determinants of capital structure choice. The Journal of Finance. 1988;43(1):1-19. DOI: $10.2307 / 2328319$

47. Tong J., Bremer M. Stock repurchases in Japan: A solution to excessive corporate saving? Journal of the Japanese and International Economies. 2016;41:41-56. DOI: $10.1016 /$ j.jjie.2016.06.002

48. Wang C.-S., Strong N., Tung S., Lin S. Share repurchases, the clustering problem, and the free cash flow hypothesis. Financial Management. 2009;38(3):487505. DOI: 10.1111/j.1755-053X.2009.01045.x

49. Whited T. Debt, liquidity constraints, and corporate investment: Evidence from panel data. The Journal of Finance. 1992;47(4):1425-1460. DOI: $10.2307 / 2328946$

50. Zhang H. Share price performance following actual share repurchases. Journal of Banking \& Finance. 2005;29(7):1887-1901. DOI: 10.1016/j. jbankfin.2004.06.038 